\title{
Effect of mentha on performance, haematological and biochemical parameters in laying hens
}

\author{
A. Rahman ${ }^{\# 1,2}$, I. Bayram ${ }^{2}$ \& E.E. Gultepe ${ }^{2}$ \\ ${ }^{1}$ University of Veterinary and Animal Sciences, Department of Animal Sciences, Lahore (Jhang Campus) Pakistan. \\ ${ }^{2}$ Afyon Kocatepe University, Department of Animal Nutrition and Nutritional Disorders, Afyonkarahisar, Turkey.
}

(Submitted 17 July 2020, Accepted 5 February 2021, Published 23 March 2021)

\begin{abstract}
Copyright resides with the authors in terms of the Creative Commons Attribution 4.0 South African Licence.
See: http://creativecommons.org/licenses/by/4.0/za

Condition of use: The user may copy, distribute, transmit and adapt the work, but must recognise the authors and the South African Journal of Animal Science.
\end{abstract}

\begin{abstract}
Effects of Mentha piperita (peppermint) extract and juice on performance and immune parameters were evaluated in laying hens. A total of 252 Babcock laying hens were allocated to seven treatments with four replications of nine hens. The control hens were fed a basal diet without supplementation. Other hens were given diets supplemented with mentha extract (ME) at 50 (50ME), 100 (100ME), and 200 (200ME) $\mathrm{mg} / \mathrm{kg}$ of feed or with 50 mentha juice $(50 \mathrm{MJ}), 100(100 \mathrm{MJ})$ and $200(200 \mathrm{MJ}) \mathrm{mg} / \mathrm{L}$ that was provided in the drinking water. No significant differences were detected among treatments in bodyweight, feed intake, egg mass, egg production, eggshell breaking strength, Haugh unit, and haematological and serological parameters. The ratio of gram feed to gram egg mass (feed conversion) was significantly better in the birds that received 100ME and 200ME compared with the control hens. The yolk colour index was higher in mid trial analysis (28th day). Thus, although the ME supplementation had a positive effect on feed conversion ratio and egg yolk colour at dosage rates up to $200 \mathrm{mg} / \mathrm{kg}$, further research is needed to establish the efficacy of this herbal product and to determine the most appropriate amount to include in diets for laying hens.
\end{abstract}

Keywords: antibiotics, immuno-modulator, mentha juice, phytobiotics

\#Corresponding author: abdurrehman@uvas.edu.pk

\section{Introduction}

Various types of phytogenic product - such as mentha, garlic, anise, cinnamon, coriander, oregano, chili, pepper, rosemary, rosehip and thyme - may be used as additives to enhance performance and modulate gut health in poultry (Criste et al., 2017). Phyto-additives have a positive effect on performance parameters, including egg production, egg quality (Rahimi et al., 2011; Khan et al., 2012), the immune system and antioxidant status (Gill, 2000; Abd El-Hack \& Alagawany, 2015). Phytobiotic products improved performance by increasing the digestibility and retention of nutrients, increasing the secretion of digestive enzymes and mucous production, and improving gut health status and microbial population to maintain production performance during heat stress (Criste et al., 2017). Among these, mentha is of great interest because of its health-modulating effects. Dietary supplementation of peppermint leaves by up to $2 \%$ in a layer hen diet may enhance the production performance and egg quality and reduce cholesterol level (AbdelWareth \& Lohakare, 2014). Inclusion of thyme herbal extracts in poultry diets was witnessed to improve performance, immunity and antioxidant activity and biochemical profile (Abd El-Hack \& Alagawany, 2015). Supplementation of mint in the feed of laying hens decreased serum cholesterol significantly (Abdel-Wareth \& Lohakare 2014; Abo-Ghanima et al., 2020) and increased calcium and phosphorous. Peppermint extract reduced the blood urea level, triglyceride level and cholesterol in broilers when fed in drinking water (Roozbeh et al., 2013) and had a mild effect on immunity enhancement. Supplementation of mentha extract in drinking water decreased plasma total cholesterol, triglyceride, low density lipoproteins (LDL), and liver synthesis of lipid (Rahim et al., 2012). Spearmint (Mentha spicata) extract may improve egg production, egg shell thickness and yolk weight, whereas it may decrease serum total cholesterol, triglycerides and LDL concentration in laying hens, but had no effect on the immune system (Behboud et al., 2011). Pennyroyal (Mentha pulegium) powder and its extract had a positive influence on egg production performance, egg quality, blood biochemical and immunity parameters in laying hens (Paymard et al., 2013). To the best of the 
authors' knowledge, few research studies on mentha in broilers have shown its positive effect on performance (Ocak et al., 2008; Toghyani et al., 2010) and data on the use of mentha are scarce, especially as related to its extract and juice in layer diets. Therefore, this study was designed to investigate the effects of ME and mentha juice on the performance, egg quality traits and biochemical and immunity parameters in laying hens. It was aimed to use ME and juice as safe additives with positive effects on performance and immune status.

\section{Materials and methods}

This study was conducted at the experimental animal farm of Afyon Kocatepe University under the project approved by BAPK 15.SAĞ.BIL.23. The Ethics Committee of the Faculty of Veterinary Medicine approved the study (case AKUHADYEK-455.15). The results from this study that pertained to the maintenance of egg quality during storage were presented earlier (Rahman et al., 2017).

Two hundred and fifty-two 21-week old Babcock (Hendrix Genetics, Boxmeer, The Netherlands laying hens were procured for this study. The birds were fed a corn-soybean-based basal diet without mentha supplementation during the adaptation period before the trial (Table 1). The basal diet was formulated according to NRC (1994) recommended allowances for laying hens (Table 2). The trial period was 60 days (four days for adaptation to the treatments and 56 days for data collection. The birds were housed in cages with 16 hours of light and eight hours of darkness. Before starting the study, all birds were vaccinated against Newcastle Disease via their drinking water.

Table 1 Ingredient composition of the basal diet provided to laying hens

\begin{tabular}{|c|c|}
\hline Feed ingredients & Inclusion level, \% \\
\hline Corn & 52.0 \\
\hline Sunflower meal & 8.1 \\
\hline Soybean meal & 12.2 \\
\hline Thermally treated full-fat soya & 12.0 \\
\hline Limestone & 9.0 \\
\hline Meat and bonemeal & 3.7 \\
\hline Sunflower oil & 1.5 \\
\hline Vitamin-mineral mix ${ }^{1}$ & 0.25 \\
\hline Methionine & 0.15 \\
\hline Salt & 0.3 \\
\hline Rovabio $^{2}$ & 0.1 \\
\hline Phytase supplement, providing 500000 mg phytase per kg diet & 0.7 \\
\hline
\end{tabular}

\footnotetext{
${ }^{1}$ Vitamin $A: 12000000 \mathrm{IU}$, vitamin $\mathrm{D}_{3}: 3000000 \mathrm{IU}$, vitamin $\mathrm{E}: 35000 \mathrm{IU}$, vitamin $\mathrm{K}_{3}: 3500 \mathrm{IU}$, vitamin $\mathrm{B}_{1}: 2750 \mathrm{IU}$, vitamin $B_{2}: 5500 \mathrm{IU}$, nicotinamide: $30000 \mathrm{IU}$, Ca-D pantothenate: $10000 \mathrm{IU}$, vitamin $\mathrm{B}_{6}: 4000 \mathrm{IU}$, vitamin $\mathrm{B}_{12}: 15 \mathrm{IU}$, folic acid: 1000 IU, D-Biotin: 50 IU, choline chloride: IU, manganese: 80000 mg, Iron: 60000 mg, zinc: 60000 mg, copper: 5000 mg, iodine: $2000 \mathrm{mg}$, cobalt: $500 \mathrm{mg}$, selenium: $150 \mathrm{mg}$, antioxidant: $15000 \mathrm{mg} / \mathrm{kg}$

210 million IU beta xylanase and 17.5 million IU beta glucanase per kg diet
}

The birds were randomly allotted to seven treatments with 36 birds in each group, and each group was subdivided into four replicates of nine birds. The control hens were fed a basal diet without supplementation. The other hens were given the basal diet supplemented with ME. Thus 50ME, 100ME and 200ME diets contained ME at 50,100 and $200 \mathrm{mg} / \mathrm{kg}$ of feed. The $50 \mathrm{MJ}, 100 \mathrm{MJ}$ and $200 \mathrm{MJ}$ treatments provided 50,100 and $200 \mathrm{mg} / \mathrm{L}$ of mentha in the drinking water. The mentha extract was procured from Ideal Animal Health Technologies, Izmir, Turkey. It was extracted by homogenizing clean fresh mentha plants in a blender and filtering the homogenate. The extract was mixed with the diet each day with sunflower oil to prevent loss or oxidative spoilage. Similarly, the juice was poured into fresh drinking water each day. Feed and drinking water were available ad libitum throughout the trial. Fatty acid methyl esters from the extract and juice were prepared and analysed (Canbay et al., 2011). Samples of the basal diet were analysed to determine their nutrient composition according to AOAC (1990) 
Table 2 Nutrient composition of the basal diet for laying hens as analysed and as calculated

\begin{tabular}{lrc}
\hline Nutrient & Analysed, \% & Calculated, \% \\
\hline Dry matter & 89.88 & 88.50 \\
Ash & 14.29 & 13.50 \\
Crude fat & 6.85 & 6.50 \\
Crude fibre & 5.30 & 4.60 \\
Crude protein & 18.60 & 18.00 \\
Starch & 28.11 & 2800.00 \\
Sugar & 3.75 & 4.00 \\
Metabolizable energy, Kcal/kg & 2721.87 & 0.44 \\
Calcium & & 0.17 \\
Phosphorus & & \\
Sodium & & \\
Nitrogen free extract & 44.84 & \\
\end{tabular}

Average daily feed consumption, egg production, egg mass and feed conversion ratio (FCR) were calculated in all groups. Daily egg mass was calculated by multiplying the total number of eggs produced weekly by the average egg weight and dividing the product by the number of days of collection. Daily feed intake and egg mass were then used to calculate FCR. The bodyweight of each bird was recorded at the start of the trial and at the end of the study (day 56). On days 1, 28, and 56 of the trial, three eggs were collected from each replicate of each treatment (84 eggs per day) to analyse egg breaking strength (Orka egg force reader, EF 0468-2011, Orka Food Technology, Wanchai, Hong Kong), egg weight, egg yolk colour, and Haugh unit (Sanovo Engineering Egg Analyzer, Sanovo Technology Group A/S. Odense, Denmark). These analyses were completed on the same day that the eggs were collected. At the end of the trial, three eggs from each replicate were collected, and the egg yolk was separated and diluted with normal saline to analyse cholesterol levels.

At the end of trial, blood samples were collected from the heart of three live birds in each replicate using a 10-ml syringe. Five $\mathrm{ml}$ of blood was drawn into tubes coated with the anticoagulant ethylenediaminetetraacetic acid. Total leukocyte count (TLC), lymphocyte count, neutrophil count, monocyte count, haemoglobin level, haematocrit percentage, mean corpuscular volume (MCV), mean corpuscular haemoglobin $(\mathrm{MCH})$, mean corpuscular haemoglobin concentration $(\mathrm{MCHC})$, platelet count and mean platelet volume (MPV) were determined for each sample using a blood chemistry analyser (Mindray BC 2800 Vet, Shenzhen, China). An additional $5 \mathrm{ml}$ blood sample was collected in a tube without anticoagulant and centrifuged at $7000 \mathrm{rpm}$ for 10 minutes, after which time the serum was collected and stored at $-20^{\circ} \mathrm{C}$ until it was analysed for serum glucose, cholesterol, low density lipoproteins (LDL), high density lipoproteins (HDL), aspartate aminotransferase (AST), alanine aminotransferase (ALT), total protein, egg cholesterol, calcium and phosphorus level by a completely automated enzyme-linked immunosorbent assay (Elisa) (Chemwell 2910, Awareness Tech. Inc. ${ }^{\circledR}$, USA; ALT: AL021, BEN S.R.L. ${ }^{\circledR}$; Italy, AST: AS071, BEN S.R.L. ${ }^{\circledR}$, Italy). Serum IgG (immunoglobulin $G$ ) was also analysed for serum antibody titre against the ND vaccine by the ELISA method.

The PASW statistics software (IBM Inc., Armonk, New York, USA) was used in the statistical evaluation of the data. The Kolmogorov-Smirnov test was used to examine the normality of the distribution of the data. One-way analysis of variance was applied to the replicate means to determine the overall significance of treatment effects. For the independent variables, Kruskal-Wallis $\mathrm{K}$ sample test was applied using post-hoc analysis with Dunn-Bonferroni test to assess differences between the treatment means. The criterion $P \leq 0.05$ was accepted as indicating statistical significance.

\section{Results and Discussions}

Mentha extract and MJ were characterized for their fatty acid composition (Table 3). 
Table 3 Important fatty acid methyl esters in mentha extract and juice

\begin{tabular}{lrr}
\hline Fatty acid methyl ester & Extract & Juice \\
\hline Palmitic acid (C16:0) & 19.44 & 24.96 \\
Palmitoleic acid (C16:1) & 0.26 & 0.25 \\
Heptadecanoic acid (C17:0) & 0.25 & 0.25 \\
Stearic acid (C18:0) & 56.20 & 53.11 \\
Oleic acid (18:1n9c) & 3.20 & 2.09 \\
Linoleic acid (C18:2n6c) & 4.79 & 4.06 \\
Y-Linolenic acid (C18:3n6) & 8.79 & 8.81 \\
Eicosanoic acid (C20:0) & 1.62 & 0.51 \\
\hline
\end{tabular}

There was no significant difference $(P>0.05)$ in the bodyweight among the groups during the study (Table 4). Similarly, bodyweight was not affected by supplementation with extracts of cinnamon, capsicum, oregano and thyme (Lippens et al., 2005). However, Popović et al. (2016) observed increased bodyweight as a consequence of herbal supplementation.

Table 4 Bodyweight and bodyweight change during the experimental period in which laying hens received supplemental mentha extract or mentha juice

\begin{tabular}{rrrr}
\hline Treatment & Initial bodyweight, g & Final bodyweight, g & Bodyweight change, g \\
\hline Control & 1551.27 & 1583.93 & 40.95 \\
$50 \mathrm{ME}^{*}$ & 1514.00 & 1588.00 & 84.89 \\
$100 \mathrm{ME}$ & 1555.28 & 1600.00 & 44.45 \\
$200 \mathrm{ME}$ & 1518.65 & 1588.49 & 71.63 \\
$50 \mathrm{MJ}^{\star *}$ & 1535.00 & 1582.76 & 46.73 \\
$100 \mathrm{MJ}$ & 1553.94 & 1638.79 & 86.06 \\
$200 \mathrm{MJ}$ & 1567.35 & 1624.62 & 46.97 \\
SE & 6.95 & 7.03 & 7.64 \\
$P$-value & 0.31 & 0.20 & 0.46
\end{tabular}

50ME, 100ME, 200ME: birds fed diets supplemented with 50,100 and $200 \mathrm{mg} / \mathrm{kg}$ of feed of mentha extract; $50 \mathrm{MJ}$, $100 \mathrm{MJ}, 200 \mathrm{MJ}$ : birds whose drinking water was enriched with 50,100 and $200 \mathrm{mg} / \mathrm{L}$ of mentha

Likewise, no difference $(P>0.05)$ that was attributable to the treatments was observed in the feed intake (Table 5). Thus, these results are contradictory to those findings in which supplementation of laying hens with up to $2 \%$ ground peppermint leaves enhanced the feed intake during the late laying period (AbdelWareth \& Lohakare, 2014). These findings were counter to previous results that showed that the addition of extracts from Allium sativum, Punica granatum and Thymus vulgaris or Salvia rosmarinus and Cinnamomum verum to drinking water at $0.5 \mathrm{ml} / \mathrm{L}$ reduced the intake in laying hens (Sharma et al., 2020; Abo-Ghanima et al., 2020). The differences between the present study and previous reports might be because of differences in the mechanism of action of the herbal products, the form in which these products were provided, and in the birds that were studied. 
Table 5 Weekly average daily feed consumption of laying hens that received diets supplemented with mentha extract or juice

\begin{tabular}{|c|c|c|c|c|c|c|c|c|c|}
\hline \multirow{2}{*}{ Treatment } & \multicolumn{9}{|c|}{ Weeks } \\
\hline & 1 & 2 & 3 & 4 & 5 & 6 & 7 & 8 & $1-8$ \\
\hline Control & 96.31 & 101.43 & 103.62 & 109.62 & 109.96 & 110.51 & 102.97 & 104.65 & 104.16 \\
\hline 50ME & 96.33 & 99.50 & 100.11 & 104.11 & 102.47 & 100.23 & 99.43 & 96.11 & 99.17 \\
\hline 100ME & 97.12 & 101.15 & 105.19 & 107.01 & 107.44 & 107.30 & 103.47 & 100.95 & 102.87 \\
\hline $200 \mathrm{ME}$ & 86.85 & 99.06 & 100.15 & 103.62 & 107.25 & 105.01 & 107.02 & 101.66 & 100.64 \\
\hline $50 \mathrm{MJ}$ & 95.69 & 98.49 & 103.12 & 106.73 & 108.87 & 108.38 & 103.54 & 102.60 & 102.85 \\
\hline $100 \mathrm{MJ}$ & 94.13 & 100.71 & 104.87 & 108.96 & 107.61 & 109.30 & 108.18 & 109.29 & 104.40 \\
\hline $200 \mathrm{MJ}$ & 100.22 & 100.54 & 108.03 & 109.75 & 107.13 & 110.58 & 104.49 & 109.68 & 105.69 \\
\hline SE & 1.35 & 0.95 & 1.07 & 1.18 & 1.21 & 1.30 & 1.46 & 1.76 & 0.98 \\
\hline$P$-value & 0.23 & 0.99 & 0.44 & 0.73 & 0.82 & 0.34 & 0.81 & 0.43 & 0.14 \\
\hline
\end{tabular}

50ME, 100ME, 200ME birds fed diets supplemented with 50, 100 and $200 \mathrm{mg} / \mathrm{kg}$ of feedof mentha extract; $50 \mathrm{MJ}$, $100 \mathrm{MJ}, 200 \mathrm{MJ}$ birds whose drinking water was enriched with 50,100 and $200 \mathrm{mg} / \mathrm{L}$ of menthe

No differences $(P>0.05)$ were detected among the treatments in mean egg mass (Table 6). Contrary to the present results Khan et al. (2012), Abdel-Wareth et al. (2013), Abdel-Wareth and Lohakare (2014), and Abo-Ghanima et al. (2020) claimed that addition of herbs such as thyme, oregano, rosemary, cinnamon essential oils and powdered mint leaves improved egg mass and egg weight for hens that were $68-72$ weeks old. Mansoub (2011) reported that supplemental thyme improved egg weight and egg production. Similar to the present results, Ghasemi et al. (2010) and Sharma et al. (2020) reported that supplementation of the diet for laying hens with medicinal herbs (garlic, thyme and essential oils) did not improve egg weight and mass. The present finding of no difference in egg mass is consistent with the absence of a change in the egg weight and egg production. Effects of phytobiotics are commonly thought to vary depending on the type of product, that is, extract, juice or leaf powder, and the amount of bioactive substance being provided to the birds.

Table 6 Weekly egg mass of laying hens that received diets supplemented with mentha extract or juice

\begin{tabular}{|c|c|c|c|c|c|c|c|c|c|}
\hline \multirow{2}{*}{ Treatment } & \multicolumn{9}{|c|}{ Weeks } \\
\hline & 1 & 2 & 3 & 4 & 5 & 6 & 7 & 8 & $1-8$ \\
\hline Control & 48.00 & 51.62 & 52.96 & 53.00 & 53.90 & 57.65 & 52.49 & 54.12 & 52.97 \\
\hline $50 \mathrm{ME}$ & 46.13 & 51.08 & 51.22 & 55.24 & 56.16 & 54.76 & 53.08 & 54.55 & 52.78 \\
\hline 100ME & 50.06 & 53.36 & 55.18 & 54.59 & 57.86 & 58.23 & 54.93 & 59.63 & 55.48 \\
\hline 200ME & 44.49 & 48.17 & 50.87 & 50.32 & 52.32 & 53.46 & 53.55 & 58.54 & 51.47 \\
\hline $50 \mathrm{MJ}$ & 44.17 & 50.14 & 49.90 & 51.17 & 54.58 & 55.93 & 56.71 & 57.92 & 52.56 \\
\hline $100 \mathrm{MJ}$ & 46.34 & 47.66 & 48.72 & 51.87 & 53.97 & 53.79 & 52.07 & 54.32 & 51.09 \\
\hline $200 \mathrm{MJ}$ & 53.11 & 52.47 & 54.29 & 55.95 & 56.42 & 58.32 & 52.57 & 56.09 & 55.03 \\
\hline SE & 1.13 & 0.94 & 0.89 & 0.83 & 0.67 & 0.84 & 0.61 & 0.72 & 0.60 \\
\hline$P$-value & 0.34 & 0.66 & 0.44 & 0.49 & 0.37 & 0.56 & 0.39 & 0.19 & 0.39 \\
\hline
\end{tabular}

50ME, 100ME, 200ME birds fed diets supplemented with 50, 100 and $200 \mathrm{mg} / \mathrm{kg}$ of feedof mentha extract; $50 \mathrm{MJ}$, $100 \mathrm{MJ}, 200 \mathrm{MJ}$ birds whose drinking water was enriched with 50,100 and $200 \mathrm{mg} / \mathrm{L}$ of mentha, respectively

After feeding supplemental ME for eight weeks, FCR was improved $(P<0.05)$ for those birds in $100 \mathrm{ME}$ and 200ME relative to the control diet (Table 7). It has been claimed herbal supplements do not affect FCR in laying hens (Christaki et al., 2012; Ghasemi et al., 2010; Abo-Ghanima et al., 2020). However, other 
studies indicated beneficial effects on FCR from feeding herbal products to laying hens (Bolukbasi \& Erhan 2007; Lippens et al., 2005; Rahimi et al., 2011; Abdel-Wareth \& Lohakare, 2014; Sharma et al., 2020). The change in FCR at week 8 without contaminant changes being detected in feed intake might have resulted from the numerical increase in egg mass in $100 \mathrm{ME}$ and $200 \mathrm{ME}$, despite there being insufficient statistical power to detect these differences.

Table 7 Weekly feed conversion ratios for laying hens that received diets supplemented with mentha extract or juice

\begin{tabular}{lccccccccc}
\hline \multirow{2}{*}{ Treatment } & \multicolumn{10}{c}{ Weeks } \\
\cline { 2 - 10 } & 1 & 2 & 3 & 4 & 5 & 6 & 7 & 8 & $1-8$ \\
\hline Control & 2.01 & 1.97 & 1.92 & 2.00 & 2.04 & 1.92 & 1.96 & $1.93^{\text {ab }}$ & 1.97 \\
50ME & 2.13 & 1.96 & 1.96 & 1.80 & 1.82 & 1.83 & 1.88 & $1.76^{\text {bc }}$ & 1.88 \\
100ME & 1.95 & 1.90 & 1.93 & 1.86 & 1.86 & 1.84 & 1.88 & $1.69^{\mathrm{c}}$ & 1.86 \\
200ME & 1.97 & 2.06 & 1.97 & 1.96 & 2.08 & 2.00 & 2.02 & $1.74^{\mathrm{c}}$ & 1.96 \\
$50 \mathrm{MJ}$ & 2.18 & 1.98 & 2.08 & 2.02 & 2.00 & 1.94 & 1.82 & $1.77^{\text {bc }}$ & 1.96 \\
100MJ & 2.06 & 2.15 & 2.16 & 1.97 & 2.00 & 2.04 & 2.08 & $2.01^{\text {a }}$ & 2.05 \\
200MJ & 1.89 & 1.93 & 1.97 & 1.91 & 1.90 & 1.90 & 2.00 & $1.96^{\mathrm{a}}$ & 1.92 \\
SE & 0.04 & 0.03 & 0.03 & 0.03 & 0.04 & 0.03 & 0.04 & 0.03 & 0.02 \\
$P$-value & 0.65 & 0.52 & 0.46 & 0.61 & 0.41 & 0.60 & 0.52 & $<0.01$ & 0.08
\end{tabular}

${ }^{a, b, c}$ At week 8, means with a common superscript do on differ with probability $P \leq 0.05$

$50 \mathrm{ME}, 100 \mathrm{ME}, 200 \mathrm{ME}$ birds fed diets supplemented with 50,100, and $200 \mathrm{mg} / \mathrm{kg}$ of feedof mentha extract; $50 \mathrm{MJ}$, $100 \mathrm{MJ}, 200 \mathrm{MJ}$ birds whose drinking water was enriched with 50,100 , and $200 \mathrm{mg} / \mathrm{L}$ of menthe

There were no detectable differences in egg production percentage, with a slight numerical increase in production percentage in 100ME (Table 8). Similarly, Mahmoud et al. (2010) and Ghasemi et al. (2010) found that the provision of garlic juice, garlic powder or thyme powder had no effect on egg production in laying hens. However, there are numerous reports of increased egg production resulting from herbal supplementation of laying hens (Bölükbaşi \& Erhan, 2007; Rahimi et al., 2011; Khan et al., 2012; Mansoub, 2011; Sharma et al., 2020; Abo-Ghanima et al., 2020). Abdel-Wareth and Lohakare (2014) also stated that inclusion of powdered peppermint leaves by up to $2 \%$ in the diet of laying hens increased their egg production.

Egg breaking strength $(\mathrm{EBS})$ varied $(P<0.05)$ among the treatment groups at the beginning of the experimental period. This must be the result of the randomization of birds to treatments rather than an effect of the treatments because no differences should exist on day zero because treatments that were only just being applied simultaneously. The egg yolk colour index was higher $(P<0.05)$ in all supplemented groups on day 28 of the trial collection compared with the control group. The Haugh unit remained unchanged during the trial $(P>0.05)$ (Table 9). Khan et al. (2012) claimed that the addition of garlic had a positive effect on egg quality parameters. Sharma et al. (2020) and Bölükbaşi and Erhan (2007) reported that the addition of herbs and their extracts blended from Allium sativum, Punica granatum and Thymus vulgaris in diets of laying hens increased egg quality parameters, that is, shell thickness, yolk colour and the Haugh unit. Mansoub (2011) found that the addition of thyme in the diets of laying hens enhanced the egg yolk index significantly. Mahmoud et al. (2010) and Abo-Ghanima et al. (2020) explained similar results of improved HU in administration of phytogenic products (garlic juice, rosemary, and cinnamon essential oils) in laying hen diets. Other researchers (Nichol \& Steiner, 2008; Navid et al., 2013) claimed that the addition of herbs and their products had no effect on egg quality traits. In other studies, it was determined that the addition of thyme and oregano powder did not affect egg quality parameters (Abdel-Wareth et al., 2013; Ghasemi, et al., 2010). Saki et al. (2014) declared that supplementation of phytogenic feed additives did not change egg quality. Yalcin et al. (2006) reported that no significant effects were obtained by supplementation of 5 and 10 $\mathrm{g} \mathrm{kg-1}$ garlic powder on the albumen index, eggshell thickness and Haugh unit values of eggs. The positive effect of mentha supplementation on EBS and yolk colour might be because of the enhanced activity of the digestive system resulting in improved utilization of feed nutrients with the help of digestive enzymes boosted by herbal additives. 
Table 8 Weekly egg production percentage of laying hens that received diets supplemented with mentha extract or juice

\begin{tabular}{|c|c|c|c|c|c|c|c|c|c|}
\hline \multirow{2}{*}{ Treatment } & \multicolumn{9}{|c|}{ Weeks } \\
\hline & 1 & 2 & 3 & 4 & 5 & 6 & 7 & 8 & $1-8$ \\
\hline Control & 86.51 & 89.29 & 89.47 & 94.05 & 93.65 & 94.49 & 88.99 & 90.82 & 90.91 \\
\hline 50ME & 82.14 & 92.06 & 89.29 & 93.25 & 94.44 & 93.65 & 88.89 & 93.25 & 90.87 \\
\hline 100ME & 88.10 & 91.67 & 93.25 & 93.25 & 98.81 & 97.62 & 92.63 & 97.22 & 94.07 \\
\hline 200ME & 79.76 & 80.95 & 86.11 & 86.11 & 87.70 & 87.30 & 88.49 & 93.06 & 86.19 \\
\hline $50 \mathrm{MJ}$ & 79.37 & 87.30 & 87.70 & 88.89 & 92.06 & 92.86 & 94.84 & 96.82 & 89.98 \\
\hline $100 \mathrm{MJ}$ & 82.14 & 84.52 & 84.13 & 86.51 & 91.27 & 89.29 & 88.06 & 87.50 & 86.68 \\
\hline $200 \mathrm{MJ}$ & 92.86 & 90.87 & 92.54 & 97.62 & 98.02 & 97.12 & 90.16 & 89.95 & 93.82 \\
\hline SE & 1.87 & 1.61 & 1.45 & 1.49 & 1.22 & 1.20 & 1.18 & 1.23 & \\
\hline$P$-value & 0.45 & 0.51 & 0.67 & 0.32 & 0.18 & 0.18 & 0.74 & 0.30 & 0.32 \\
\hline
\end{tabular}

50ME, 100ME, 200ME: birds fed diets supplemented with 50, 100 and $200 \mathrm{mg} / \mathrm{kg}$ of feedof mentha extract; $50 \mathrm{MJ}$, $100 \mathrm{MJ}, 200 \mathrm{MJ}$ : birds whose drinking water was enriched with 50,100 and $200 \mathrm{mg} / \mathrm{L}$ of mentha, respectively

Table 9 Time course of egg breaking strength, yolk colour index and Haugh unit of laying hens receiving diets supplemented with mentha extract or juice

\begin{tabular}{lccccccccc}
\hline Treatment & \multicolumn{3}{c}{ Egg breaking strength } & \multicolumn{3}{c}{ Egg yolk colour } & \multicolumn{3}{c}{ Haugh unit } \\
\hline Day & 0 & \multicolumn{1}{c}{28} & 56 & 0 & 28 & 56 & 0 & 28 & 56 \\
\hline \multicolumn{1}{c}{ Control } & $45.26^{\mathrm{cb}}$ & 51.19 & 55.99 & 12.00 & $9.75^{\mathrm{b}}$ & 11.18 & 82.68 & 60.15 & 63.53 \\
$50 \mathrm{ME}$ & $55.62^{\mathrm{a}}$ & 47.71 & 49.60 & 12.75 & $12.50^{\mathrm{a}}$ & 11.67 & 80.62 & 68.98 & 72.48 \\
$100 \mathrm{ME}$ & $41.16^{\mathrm{c}}$ & 50.59 & 44.70 & 11.58 & $11.75^{\mathrm{a}}$ & 11.67 & 83.02 & 77.66 & 63.50 \\
$200 \mathrm{ME}$ & $44.55^{\mathrm{bc}}$ & 49.37 & 46.72 & 11.40 & $12.08^{\mathrm{a}}$ & 12.09 & 85.99 & 65.45 & 70.15 \\
$50 \mathrm{MJ}$ & $50.79^{\mathrm{ab}}$ & 52.55 & 48.68 & 11.83 & $11.92^{\mathrm{a}}$ & 10.42 & 82.29 & 68.78 & 69.52 \\
$100 \mathrm{MJ}$ & $47.26^{\mathrm{abc}}$ & 51.25 & 46.83 & 11.17 & $11.58^{\mathrm{a}}$ & 11.92 & 82.16 & 58.53 & 50.40 \\
$\quad 200 \mathrm{MJ}$ & $42.50^{\mathrm{bc}}$ & 50.50 & 47.96 & 12.58 & $11.45^{\mathrm{a}}$ & 11.67 & 76.86 & 58.75 & 57.43 \\
SE & 1.15 & 0.90 & 1.02 & 0.19 & 0.21 & 0.19 & 0.77 & 2.49 & 2.75 \\
$P$-value & $<0.01$ & 0.87 & 0.09 & 0.21 & 0.02 & 0.28 & 0.09 & 0.35 & 0.32 \\
& & & & & & & & & \\
\hline
\end{tabular}

$\overline{a, b, c}$ within a column, means with a common superscript do on differ with probability $P \leq 0.05$

$50 \mathrm{ME}, 100 \mathrm{ME}, 200 \mathrm{ME}$ : birds fed diets supplemented with 50,100 and $200 \mathrm{mg} / \mathrm{kg}$ of feed of mentha extract; $50 \mathrm{MJ}$,

$100 \mathrm{MJ}, 200 \mathrm{MJ}$ : birds whose drinking water was enriched with 50,100 and $200 \mathrm{mg} / \mathrm{L}$ of mentha

No effects that could be attributed to the treatments were detected $(P>0.05)$ on any of the traits measured by the haematological total profile (Table 10). In contrast, Ghasemi et al. (2010) found the addition of $0.2 \%$ medicinal herbs in a ration for laying hens increased lymphocytes, whereas other haematological traits remained unchanged. Abo-Ghanima et al. (2020) reported that addition of essential oils in laying hen diets increased lymphocytes and monocytes without producing changes in the counts of white blood cells (WBC) or red blood cells (RBC), packed cell volume (PCV) percentage and haemoglobin ( $\mathrm{Hb}$ ) percentage.

Biochemical constituents in serum are closely associated with health status of the birds. In this study, no differences were detected among the treatment groups $(P>0.05)$, except that 200ME produced significantly lower IgG values compared with the control (Table 11). In contrast, supplementation of thyme significantly reduced total serum protein when fed at $9 \mathrm{~g} / \mathrm{kg}$ of feed in layers (Abd El-Hack \& Alagawany, 2015). Similarly, total cholesterol and LDL cholesterol of laying hens were reduced significantly with 3 and 6 $\mathrm{g} / \mathrm{kg}$ feed of thyme (Abd El-Hack \& Alagawany, 2015). In the same study, immunity was improved with higher IgG values observed with supplemental thyme (Abd El-Hack \& Alagawany, 2015). Similar to the present 
Table 10 Haematological profiles of laying hens that were fed peppermint (mentha) extract or juice supplemented diets for 56 days

\begin{tabular}{|c|c|c|c|c|c|c|c|c|c|c|c|c|}
\hline Treatment & TLC & $\begin{array}{l}\text { Lympho- } \\
\text { cyte count }\end{array}$ & $\begin{array}{l}\text { Neutrophil } \\
\text { count }\end{array}$ & $\begin{array}{l}\text { Monocyte } \\
\text { count }\end{array}$ & $\begin{array}{l}\text { Red blood } \\
\text { cell count }\end{array}$ & $\mathrm{HB}, \mathrm{g} / \mathrm{dl}$ & $\begin{array}{l}\text { Haemato- } \\
\text { crit, \% }\end{array}$ & MCV & $\mathrm{MCH}$ & $\mathrm{MCHC}$ & $\begin{array}{c}\text { Platelet } \\
\text { count }\end{array}$ & MPV \\
\hline Control & 2.47 & 1.53 & 0.56 & 0.04 & 2.51 & 10.26 & 33.78 & 110.23 & $30.71^{a b}$ & 30.68 & 27.23 & 6.41 \\
\hline 50ME & 2.78 & 1.95 & 0.70 & 0.04 & 2.35 & 10.58 & 35.77 & 107.04 & $30.37^{\mathrm{abc}}$ & 30.38 & 26.81 & 6.43 \\
\hline 100ME & 2.84 & 2.02 & 0.67 & 0.04 & 2.49 & 10.68 & 35.13 & 107.80 & $29.96^{\mathrm{abc}}$ & 30.49 & 25.21 & 6.43 \\
\hline 200ME & 3.04 & 2.06 & 0.71 & 0.04 & 2.59 & 10.79 & 35.02 & 112.09 & $28.76^{\mathrm{C}}$ & 31.06 & 26.09 & 6.52 \\
\hline $50 \mathrm{MJ}$ & 2.97 & 2.15 & 0.75 & 0.04 & 2.51 & 10.62 & 36.13 & 109.15 & $30.27^{\mathrm{abc}}$ & 30.51 & 26.40 & 6.50 \\
\hline $100 \mathrm{MJ}$ & 2.99 & 2.09 & 0.78 & 0.04 & 2.57 & 10.52 & 35.54 & 108.53 & $29.29^{b c}$ & 30.19 & 26.89 & 6.60 \\
\hline $200 \mathrm{MJ}$ & 2.56 & 1.79 & 0.67 & 0.04 & 2.59 & 10.35 & 35.86 & 109.61 & $31.22^{\mathrm{a}}$ & 30.97 & 24.89 & 6.57 \\
\hline SE & 0.09 & 0.07 & 0.02 & 0.00 & 0.03 & 0.10 & 0.33 & 0.86 & 0.22 & 0.10 & 0.31 & 0.03 \\
\hline$P$-value & 0.57 & 0.33 & 0.10 & 0.06 & 0.51 & 0.86 & 0.62 & 0.78 & 0.05 & 0.24 & 0.38 & 0.65 \\
\hline
\end{tabular}

a,b,c within a column, means with a common superscript do on differ with probability $P \leq 0.05$

$50 \mathrm{ME}, 100 \mathrm{ME}, 200 \mathrm{ME}$ birds fed diets supplemented with 50,100 and $200 \mathrm{mg} / \mathrm{kg}$ of feed, respectively, of mentha extract; $50 \mathrm{MJ}, 100 \mathrm{MJ}$, $200 \mathrm{MJ}$ birds whose drinking water was enriched with 50,100 and $200 \mathrm{mg} / \mathrm{L}$ of menthe, respectively; TLC: Total leukocyte count, MCV: Mean corpuscular volume, MCH: Mean corpuscular haemoglobin, MCHC: Mean corpuscular haemoglobin concentration, MPV: Mean platelet volume

Table 11 Serum constituents and egg cholesterol of laying hens receiving peppermint (mentha) extract or juice supplemented diets for 56 days

\begin{tabular}{|c|c|c|c|c|c|c|c|c|c|c|c|}
\hline Treatment & $\begin{array}{c}\text { Glucose, } \\
\text { mg/dl }\end{array}$ & $\begin{array}{c}\text { Cholesterol, } \\
\mathrm{mg} / \mathrm{dl}\end{array}$ & $\mathrm{HDL}, \mathrm{mg} / \mathrm{dl}$ & LDL, mg/dl & AST, U/L & $\mathrm{ALT}, \mathrm{U} / \mathrm{L}$ & $\begin{array}{c}\text { Total protein, } \\
\mathrm{g} / \mathrm{dl}\end{array}$ & $\mathrm{lgG}, \mathrm{mg} / \mathrm{ml}$ & $\begin{array}{c}\text { Cholesterol, } \\
\mathrm{mg} / \mathrm{dl}\end{array}$ & $\mathrm{P}, \mathrm{mg} / \mathrm{dl}$ & $\mathrm{Ca}, \mathrm{mg} / \mathrm{d}$ \\
\hline Control & 180.64 & 72.45 & 19.73 & 21.82 & 196.00 & 0.87 & 4.16 & $4.46^{\mathrm{a}}$ & 309.10 & 3.65 & 17.73 \\
\hline $50 \mathrm{ME}$ & 184.27 & 80.18 & 19.42 & 27.00 & 174.55 & 1.04 & 4.63 & $4.19^{a b}$ & 329.09 & 4.14 & 19.08 \\
\hline 100ME & 185.00 & 72.20 & 20.40 & 20.20 & 186.30 & 0.94 & 4.37 & $2.70^{\mathrm{ab}}$ & 362.00 & 3.59 & 17.23 \\
\hline 200ME & 161.64 & 76.00 & 17.09 & 22.09 & 152.09 & 0.95 & 3.60 & $0.94^{b}$ & 350.10 & 5.31 & 15.60 \\
\hline $50 \mathrm{MJ}$ & 178.00 & 71.18 & 20.09 & 20.27 & 178.82 & 0.84 & 4.23 & $2.29^{\mathrm{ab}}$ & 357.18 & 3.75 & 17.13 \\
\hline $100 \mathrm{MJ}$ & 183.00 & 97.00 & 20.40 & 26.10 & 185.90 & 2.48 & 4.64 & $5.46^{\mathrm{ab}}$ & 321.91 & 4.11 & 18.18 \\
\hline $200 \mathrm{MJ}$ & 175.22 & 89.89 & 16.56 & 25.67 & 185.22 & 1.73 & 4.49 & $1.65^{\mathrm{ab}}$ & 284.29 & 3.96 & 19.16 \\
\hline SE & 3.14 & 5.22 & 0.43 & 1.15 & 5.73 & 0.18 & 0.14 & 0.63 & 8.99 & 0.31 & 0.55 \\
\hline$P$ value & 0.44 & 0.53 & 0.08 & 0.51 & 0.52 & 0.14 & 0.44 & 0.02 & 0.28 & 0.81 & 0.65 \\
\hline
\end{tabular}

50ME, 100ME, 200ME birds fed diets supplemented with 50, 100 and $200 \mathrm{mg} / \mathrm{kg}$ of feed, respectively, of mentha extract; $50 \mathrm{MJ}, 100 \mathrm{MJ}, 200 \mathrm{MJ}$ birds whose drinking water was enriched with 50,100 and $200 \mathrm{mg} / \mathrm{L}$ of menthe, respectively; $\mathrm{P}$ : phosphorus, Ca: calcium 
study, Saki et al. (2014) reported that dietary inclusion of phytogenic feed additives did not change the serum cholesterol and triglyceride levels in laying hens. Mansoub (2011) found that supplementation with thyme powder in layer diets did not influence the immunity in laying hens, and it showed a significant reduction in serum total cholesterol concentration, but produced no change in serum HDL, LDL and glucose concentration. Ozek et al. (2011) and Bozkurt et al. (2012) declared that essential oil mixtures did not improve the antibody titre against ND or infectious bronchitis virus in layers. Ghasemi et al. (2010) determined that the inclusion of garlic and thyme powder in laying hen diets had no effect on serological parameters, including cholesterol, TG, LDL, and HDL. Abo-Ghanima et al. (2020) reported that the addition of essential oils reduced the serum cholesterol level, AST, and ALT values, whereas it increased the concentration of serum calcium $(\mathrm{Ca})$ and serum phosphorous $(\mathrm{P})$ in laying hens. Abdel-Wareth \& Lohakare (2014) found that supplementation of peppermint leaf powder by up to $2 \%$ in laying hen diets reduced cholesterol levels, but increased serum total proteins with increasing levels of peppermint leaf powder. The literature showed the interchanging results of phytobiotic supplementation on biochemical parameters, which might be because of variable types of herbs or their products that were used in past studies with various dose levels in different species of birds.

\section{Conclusions}

Supplementation of the diets of laying hens with Mentha piperita oil at levels providing $100 \mathrm{mg} / \mathrm{kg}$ and $200 \mathrm{mg} / \mathrm{kg}$ mentha extract had positive effects on feed conversion ratio of laying hens after being fed for 8 weeks in this study. Because the rate of significant effects was approximately equal the expected false positive rate at $P=0.05$, it is suggested that additional studies should explore the efficacy of this herbal product with a wider range of doses and compare the use of extract versus juice to provide recommendations for its use in diets for laying hens.

\section{Acknowledgement}

This study was supported by the Scientific Research Projects Coordination Unit of Afyon Kocatepe University (Project Number 15.SAĞ.BíL.23).

\section{Authors' Contributions}

This work was derived from the PhD thesis of $A R$, who wrote this article too. IB conceived the idea and supervised the thesis and research. EEG analysed the data.

\section{Conflict of Interest Declaration}

The authors declare no conflict of interest regarding this article.

\section{References}

Abd El-Hack, M.E. \& Alagawany, M., 2015. Performance, egg quality, blood profile, immune function, and antioxidant enzyme activities in laying hens fed diets with thyme powder. J. Anim. Feed Sci. 24(2), 127-133.

Abdel-Wareth, A.A.A. \& Lohakare, J.D., 2014. Effect of dietary supplementation of peppermint on performance, egg quality, and serum metabolic profile of Hy-Line Brown hens during the late laying period. Anim. Feed Sci. Tech. https://doi.org/10.1016/j.anifeedsci.2014.07.007

Abdel-Wareth, A.A.A., Ismail, Z.S.H. \& Südekum, K.H., 2013. Effects of thyme and oregano on performance and egg quality characteristics of laying hens. Worlds Poult. Sci. J. 69: 1-7.

Abo-Ghanima, M.M., Elsadek, M.F., Taha, A.E., Abd El-Hack, M.E., Alagawany, M., Ahmed, B.M., Elshafie, M.M. \& ElSabrout, K., 2020. Effect of housing system and rosemary and cinnamon essential oils on layers performance, egg quality, haematological traits, blood chemistry, immunity, and antioxidant. Animals 10(2), 245. https://doi.org/10.3390/ani10020245

AOAC (Association of Official Analytical Chemists), 1990. Official methods of analysis. 15th ed. AOAC, Arlington, VA, USA.

Behboud, J., Maharam, K. \& Rezazadehreyhani, Z., 2011. Influence of different level of spearmint (Mentha spicata) extract on different parameters of laying hens. Ann. Biol. Res. 2(6), 517-521.

Bolukbasi, S.C. \& Erhan, M.K., 2007. Effect of dietary thyme (Thymus vulgaris) on laying hens performance and Escherichia coli (E. coli) concentration in feces. Int. J. Nat. Eng. Sci. 1(2), 55-58.

Bozkurt, M., Kucukyilmaz, K., Catli, A.U., Cinar, M., Bintaş, E. \& Coven, F., 2012. Performance, egg quality, and immune response of laying hens fed diets supplemented with mannan-oligosaccharide or an essential oil mixture under moderate and hot environmental conditions. Poult. Sci. 91, 1379-1386.

Canbay, H.S. \& Bardakçı, B., 2011. Determination of fatty acid, C, H, N and trace element composition in grape seed by GC/MS, FTIR, elemental analyser and ICP/OES. SDU Journal of Science (e-journal). 6(2), 140-148.

Christaki, E., Bonos, E., Giannenas, I. \& Florou-Paneri, P., 2012. Evaluation of oregano and [alpha]-tocopheryl acetate on laying Japanese quail diets. J. Basic Appl. Sci. 8(1).

Criste, R.D., Panaite, T.D., Tabuc, C., Sărăcilă, M., Șoica, C. \& Olteanu M., 2017. Effect of oregano and rosehip supplements on broiler (14-35 days) performance, carcass and internal organs development and gut health. Agro Life Scientific Journal. 6(1), 75-83. 
Ghasemi, R., Zarei, M. \& Torki, M., 2010. Adding medicinal herb to diet of laying hens and evaluating productive and egg quality characteristics. American J. of Anim. and Vet. Sci. 1557-4555.

Gill, C., 2000. Botanical feed additives. Feed. Int. 14-17.

Khan, R.U., Nikousefat, Z., Tufarelli, V., Naz, S., Javdani, M. \& Laudadio, V., 2012. Garlic (Allium sativum) supplementation in poultry diets: Effect on production and physiology. World Poultry Sci. J. 68, 417-424.

Lippens, M., Huyghebaert, G. \& Cerchiari, E., 2005. Effect of the use of coated plant extracts and organic acids as alternatives for antimicrobial growth promoters on the performance of broiler chickens. Archiv Fur Geflugelkunde. 69(6), 261-266.

Mahmoud, K.Z., Saad, M., Gharaibeh, H., Zakaria, A. \& Qatramiz, A.M., 2010. Garlic (Allium sativum) supplementation: Influence on egg production, quality, and yolk cholesterol level in layer hens. Asian-Aust. J. Anim. Sci. 23(11), 1503-1509.

Mansoub, N.H., 2011. Assessment on effect of thyme on egg quality and blood parameters of laying hens. Ann. Biol. Res. 2 (4):417-422.

Navid, J., Mozaffar, M. \& Kazem, K., 2013. Effect of dietary medicinal herbs on performance, egg quality and immunity response of laying hens. Adv. Env. Biol. 7(13), 4382-4389.

Nichol, R. \& Steiner, T., 2008. Efficacy of phytogenics in commercial Lohmann Brown layers. In: Feed ingredients and additives. Asia Pacific Conference, 5 March 2008, Bangkok, Thailand.

Ocak, N., Erener, G., Burak, A.K.F., Sungu, M., Altop, A. \& Ozmen, A., 2008. Performance of broilers fed diets supplemented with dry peppermint (Mentha piperita L.) or thyme (Thymus vulgaris L.) leaves as growth promoter source. Czech J. Anim. Sci. 53, 169-175.

Ozek, K., Wellmann, K.T., Ertekin, B. \& Tarım, B., 2011. Effects of dietary herbal essential oil mixture and organic acid preparation on laying traits, gastrointestinal tract characteristics, blood parameters and immune response of laying hens in a hot summer season. J. Anim. Feed Sci. 20, 575-586.

Paymard, J., Nobakht, A., Mazlum, F. \& Moghaddam, M., 2013. The effects of different levels of dried aerial parts powder and extract of pennyroyal (Mentha pulegium) medicinal plant on performance, egg quality, blood biochemical and immunity parameters of laying hens. Iran. J. Appl. Anim. Sci. 3(3), 589-594.

Popović, S., Puvača, N., Kostadinović, L., Džinić, N., Bošnjak, J., Vasiljević, M. \& Đuragić, O., 2016. Effects of dietary essential oils on productive performance, blood lipid profile, enzyme activity and immunological response of broiler chickens. Eur. Poult. Sci. 80, 1-12.

Rahim, A., Ali, M.A. \& Mohsen, D., 2012. Effect of mentha extract (Mentha piperita) supplementation in drinking water on performance, plasma lipoproteins, carcass charasteristic and liver color index or weight in broiler chickens. Indian J. Anim. Sci. 82(9), 1070-1074.

Rahimi, S., Teymouri, Z.Z., Karimi, T.M., Omidbaigi, R. \& Rokni, H., 2011. Effect of the three herbal extracts on growth performance, immune system, blood factors and intestinal selected bacterial population in broiler chickens.

Rahman, A., Gultepe, E.E., Uyarlar, C., Cetingul, I.S., lqbal, A. \& Bayram, I., 2017. Effect of mentha piperita (peppermint) extract and its Juice on egg quality traits during different storage time in laying hens. Kocatepe Vet. J. (10)1, 1420.

Roozbeh, F., Ali, K. \& Arash, A., 2013. Effect of artichoke leaves meal and mentha extract (Mentha piperita) on Immune cells and blood biochemical parameters of broilers. Glob. Vet. 10(1), 99-102.

Saki, A.S., Hassan, A., Siyar, S.A.H., Salari, J. \& Hashemi, M., 2014. Effect of a phytogenic feed additive on performance, ovarian morphology, serum lipid parameters and egg sensory quality in laying hen. Vet. Res. Forum. 5(4), 287-293.

Sharma, M.K., Dinh, T. \& Adhikari, P.A., 2020. Production performance, egg quality, and small intestine histomorphology of the laying hens supplemented with phytogenic feed additive. J. Appl. Poult. Res. 29(2), 362-371.

Toghyani, M., Gheisari, B., Ghalamkari, G. \& Mohammadrezaei, M., 2010. Growth performance, serum biochemistry and blood hematology of broiler chicks fed different levels of black seed (Nigella sativa) and peppermint (Mentha piperita). Livest. Sci. 129, 173-178.

Yalcin, S., Onbasilar, E.E. \& Reisli, Z., 2006. Effect of garlic powder on the performance, egg traits and blood parameters of laying hens. J. Sci. Food. Agric. 86, 1336-1339. 